\title{
Valentino Cattelan (Editor) Islamic Social Finance: Entrepreneurship, Cooperation and the Sharing Economy \\ Routledge, London, 2018, 238 pages, ISBN: 978-1-13-828030-4
}

\author{
Reviewed by: Abderrazak Belabes \\ Researcher at the Islamic Economics Institute, \\ King Abdulaziz University, Jeddah, Saudi Arabia
}

\begin{abstract}
The aim of this review is to discuss the notion of Islamic social finance, or what social finance is according to some researchers in Islamic finance, and the theoretical corpus on which it is based, as discussed in the book, both on the conceptual (tawhīdì paradigm) and teleological (maqāșid al-Sharī'ah) levels. This review goes beyond the approach that Islamic social finance refers to the social dimension of entrepreneurship financed Islamically, as advocated in the book. With reference to specialized literature in social and solidarity economy, it is argued that the object of social finance should focus on how social organizations - primarily awq $\bar{a} f$ which dates back to ancient times - provide funding to continue to play a role in societies. This means that the waqf is more than a simple financing instrument or financial engineering tool, and that the financial aspect is not the only or the main resource in the life of societies. Waqf, and all other social institutions, feed above all on the social link which is an inestimable treasure and provides protection for life. Would we exchange that which is better (social relationship) for that which is lower $(m \bar{a} l)$ ?
\end{abstract}

Keywords: Islamic social finance, Tawhīdī paradigm, Maqāṣid, Entrepreneurship, Financialism.

JEL Classification: B41, G23, Z12

KAUJIE Classification: B4, I4 


\section{Introduction}

The book is edited by Valentino Cattelan, a young Italian researcher, who initially studied law and has a great interest in Sharīah, economics and finance from Muslim perspectives, a topic which has become very in vogue. The content of the book is summarized as follows:

- Foreword by Abdullah Qurban Turkistani, the dean of the Islamic Economics Institute.

- Introduction. Islamic social finance and the importance of roots by the editor.

Part I - Islam, shared prosperity and the market as socio-economic community

- From the ontology of tawhìd to Islamic social finance: conceptualization and application by Masudul Alam Choudhury, Ari Pratiwi, and Mohammad Shahadat Hossain.

- A critical appraisal of Islamic finance in the light of maqāṣid al-Sharī ah by Atiq-ur-Rehman.

- Collaborative governance, social capital and the Islamic economic organization by Charilaos Mertzanis.

- Experiences in Translation: Islamic finance and the sharing economy by the editor.

Part II - Social impact entrepreneurship: instruments and cases

- A new form of global asset-backed debt market through șukūk by Mohamed Ariff.

- Islamic entrepreneurship and the fundraising challenge: unlocking capital via crowdfunding in the sharing economy by Houssem Eddine Bedoui and Rami Abdelkafi.

- Islamic FinTech and the paradigm shift in the financial landscape by Fatima Z. Bensar and Gonzalo Rodríguez.

- Islamic green finance: a new path to environment protection and sustainable development by Marianella Piratti and Valentino Cattelan.

- Salam finance: securing the purpose of microfinancing by Atiq-ur-Rehman.

- Waqf based takäful model: a challenge for entrepreneurship by Germán Rodríguez-Moreno.

- Zakāt: its micro-entrepreneurship model and sociohumanitarian impact by Mohd Ma'Sum Billah
The publishing house describes the book as follows:

The current dynamics of world economy show remarkable changes in the socio-economics of credit provision and entrepreneurship. If the emergence of the sharing economy is fostering innovative models of collaborative agency, networking and venture business, economic actors are also looking for a more sustainable development, able to foster profitability as well as community welfare. This book investigates Islamic social finance as a paramount example of this economy under change, where the balance between economic efficiency and social impact is contributing to the transformation of the market from an exchange- to a community-oriented institution.

The collected essays analyze the social dimension of entrepreneurship from an Islamic perspective, highlighting the extent to which the rationales of "sharing", distribution and cooperation, affect the conceptualization of the market in Islam as a place of "shared prosperity". Moving from the conceptual "roots" of this paradigm to its operative "branches", the contributing authors also connect the most recent trends in the financial market to Shari' ahbased strategies for community welfare, hence exploring the applications of Islamic social finance from the sharing economy, FinTech and crowdfunding to microcredit, waqf, zakāh, șukük and green investments.

An illuminating reference for researchers, practitioners and policy-makers dealing with the challenges of a global market where not only is diversity being perceived as a value to be fostered, but also as an important opportunity for a more inclusive economy for everybody (https://bit.ly/2FWU $1 Y q)$.

The main purpose of this methodological review is to discuss the notion of 'Islamic social finance', which is backed by a theoretical corpus on both the conceptual (tawhīdi paradigm) and the teleological (maqāssid al-Sharīah) levels. This review is conducted not on the basis of what is written in order to determine what is happening, but on the motivations behind the writing; done by apprehending the structure instead of just the form a distinction rigorously maintained by Umberto Eco (2013) to differentiate, in a way, the scholarly readings from the ordinary readings, as indicated in an interview at Yale university. 
This approach is necessary and should be unhampered by preconceived ideas and bias, especially since, on the one hand, some researchers consider Islamic finance as a form of social finance in the sense that its principles are focused on social responsibility (Schoon, 2015, p. 572). On the other hand, the purpose of social finance, as it stands in the specialized literature, is to ask how cooperatives, mutual societies, associations, foundations, and social enterprises provide their financing so that they can continue to play a role in various countries. This is demonstrated by a reference document of the Academy on the Social and Solidarity Economy of Montreal in which a group of international researchers participated (Fonteneau et al., 2011, p. 137). These organizations do not seek to maximize profit at the expense of social and environmental concerns, which explains the low level of interest in them among commercial investors. At the same time, they cannot easily raise funds on the capital market due to the triple bottom line principle, or otherwise known as TBL or 3BL, which consists of taking into account not only the financial result, but also the social and environmental balance sheet of the organization. It is not a question of grafting finance into a fashionable rhetoric of the entrepreneurial or of the sharing economy type, as evidenced by the subtitle of the book under review, without being up to date on the critical literature and the state-of-the-art research in the area, whether the myth of entrepreneurship (Le Goff, 1996; Marchesnay, 2009) or that of the sharing economy (Robinson, 2014; Stemler, 2017; Furchtgott-Roth, 2016).

Researchers in Islamic finance have an incentive to look at the history of social facts in Muslim societies rather than tackling fashionable economic notions of the cultures in question. Fashion may become outdated, as opposed to style. The notion of livelihood of social groups proves to be very useful in that it refers to the embedding of the economy in the social relations (Ibn Khaldūn, 2004, p. 137). In this context, the zakāh instituted as 'haqq ma'lüm' (known right) (Qur'ān, 70:24), intended for specified social categories, cannot be oriented a fortiori and, above all, to the financing of entrepreneurial projects. Similarly, waqf, an institution that is almost omnipresent in all strata of Muslim societies, has adapted to evolving societal needs over time that are specific to different cultural contexts. Recent research has shown that the institutions of waqf (Belabes, 2017, p. 24) and zakāh (Belabes, 2019, p. 73) appeared before the creation of the state and the market in the society of al-Madinah alMunawwarah. Under these conditions, it is the predecessor (i.e. the institutions of zakāh and waqf) that should influence the successor (i.e. the world of finance) and not the reverse. Moreover, the institution of the hisbah, instituted by the Prophet Muhammad (may the peace and blessings of Allah be upon him), shows that the market, if left without adequate supervision, can create injustice and corrupt social relations.

Under these conditions, the conceptualization of Islamic social finance from tawhīd is more a question of historical legitimization rather than the result of mature research. First, it should be noted, with reference to the Arabic language, that the word tawhìd means 'making something one', which cannot be achieved without negation and approval (i.e. the negation of everything except one). From the juristic (shar $\hat{\imath}$ ) meaning, tawhìd means there is no being worthy of worship except Allah, what concretely amounts to unifying Allah in His lordship (rubübiyyah), in His adoration (ulühiyyah) and in His names and attributes (asmā' wa șifât).

The oneness in the lordship (OL) is manifested in believing that Allah is the only Lord and Master, the only Creator, the only Sovereign who rules over all things. The oneness in adoration (OA) is manifested in believing that Allah is the only deity entitled to be worshiped, and that every object of worship besides Him is only falsity. The oneness in His names and attributes (ONA) is manifested in believing that Allah is the only One with the finest of names and the perfect attributes.

In mathematical terms, it means the following:

$$
\mathrm{OL}, \mathrm{ONA} \subset \mathrm{OA}
$$

In other words:

$$
\mathrm{OL}, \mathrm{ONA} \Rightarrow \mathrm{OA}
$$

As an inevitable consequence, under normal conditions, humans are endowed with al-fitrah (innate nature or original disposition), in reference to the word of Allah: "Am I not your Lord? They said, Yes” (Qur’ān, 7:172). 
The ontology of tawhid, which refers not to the unity of creation (Cattelan, 2018, p. 5), but to the study of tawhìd in itself; and not as it appears to us for one reason or another, but it is based on these three fundamental components that form an inseparable triptych as explained above. The Oneness of Lordship logically implies the application of the orders of Allah and the avoidance of His prohibitions without ruse or detour in all areas of life, including in the scientific field. The fundamental value that underlies tawhìd, it must be remembered, is the justice that entails giving each one what belongs to them. Putting it into practice requires rigor, integrity, and insight.

It is not a question of unity between Allah and his creatures, as suggested by the doctrine of pantheism or oneness of being (wahdat al-wujūd), which postulates that Allah and His creation are one, but of the indissoluble link between the right of Allah and the right of the creatures. In a hadìth qudsit ${ }^{-1}$, Allah the Mighty, the Venerable - said: "We have created al-māl [i.e. everything which is owned by humans, and is in their possession] ${ }^{(2}$ that they may perform

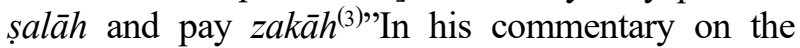
hadith, Ibn al-Qayyim (2009, p. 314) explains that the word 'perform șalāh' means "the fulfillment of Allah's rights", and the word 'pay zakāh' means "the fulfillment of human's rights".

Strictly speaking, this confusion brings out, beyond the concept of tawhid, the importance of distinguishing between the existence of the object of research (ontology), its representation (imago), and the way of knowing it (epistemology). The recent advances in methodological research show that in the social sciences, the knowledge of the object in its nature (Lawson, 2019) allows us to go beyond the epistemological questioning (how do we know what we know?), to focus on the essence of things, their multiple facets, and primary purposes. The goal is not to know for the sake of knowing, nor simply to dis-

(1) Hadìth Qudsī are the sayings of the Prophet Muhammad (Peace and Blessings of Allah be upon him) as revealed to him by the Almighty Allah.

(2) For the translation of the hadith according to the meaning, I relied on Ibn Manzūr (2003, 14, p. 152) and al-Munāwī (2005, p. 45).

(3) Ibn Hanbal (2001, 36:273), hadìth no. 21906; al-Tabarani, (1994, 3:247), hadìth no. 3301-3303; classified as șahịh by alAlbani (1995, 4:182-183), hadith no. 1639. tinguish true knowledge from false knowledge in any form whatsoever. Hence, the need to understand to compare, and compare to understand (Godelier, 2010, p. 59) - comparison in space (anthropology, sociology) and in time (archaeology, history) beyond the dichotomy between jurisprudence and finance.

Science itself marks its own limits as it progresses. This is shown by the discovery of the undecidable propositions that followed Gödel's theorem, essentially showing that whatever the logical rules in effect may be, there will always be affirmations that are neither true nor false, or even the principle of complementarity in physics, according to which particles are both corpuscular and wavelike. This puts into question our whole way of thinking and the dualisms inherited from the great scientific traditions (Belabes, 2001, p. 11). The analysis of these limits that science discovers with its own knowledge leads to questions like: what is reality? (Zwirn, 2000), and what if the scientific reality was only a way to access a certain type of object - indeed real? (Gaston-Granger, 2000). This opens up a debate about the nature of scientific knowledge and its relation to the world in which we live (Hacking, 2008).

Moreover, the word 'sources of knowledge' is more convenient than that of 'unity of knowledge'. The first refers to the sciences that draw their foundations from the Qur'ān, Sunnah and ijma $\bar{a}^{\text {c }}$ (consensus). The second is closely related to the literature on the Islamization of knowledge. What is the purpose of scientists in human and social sciences, thought to have deep knowledge in their field of research or expertise, if they all say the same thing?

The empirical impact of the supposed unity of knowledge (Cattelan, 2018, pp. 11-12) is more rhetorical than the result of an extensive study in time and space of man in society and social relations specific to each human group. The recent shift from 'History of Islamic economic thought'(Islahi, 2014) to 'Economic thinking of Arab Muslim writers' (Islahi, 2015), rightly reveals the limitations of the approach in terms of unity of knowledge and recalls the obligation to situate economic analyses according to social context, geographical space and time period (Robinson, 1962). 
The association between the social institutions of zakāh, waqf, and finance is, in fact, an implicit financialism for which social relations and real economy play a second role. The paradox is that at the moment when researchers recall that the firm is not a transactional object of financial reports or an object of financial investment, but a living entity inserted into a social fabric (Burlaud \& Colasse, 2010; Champaud, 2011), the followers of Islamic social finance equate most of the structures, organizations and social institutions with tools to finance entrepreneurship. Hence, the revealing expression: "social dimension of entrepreneurship from an Islamic perspective" (Cattelan, 2018, p. i). In other words, Islamic social finance refers to the social dimension of entrepreneurship financed Islamically, i.e., in this case, in accordance with Muslim practice or tradition. The object of social finance should focus on how social organizations, primarily $a w q \bar{a} f$, provide funding to continue to play a role in societies (Hamza, 2019). This means de facto that the financial aspect is not the only one or the main resource.

After the discourse that describes as poor the one who does not depend on consumer goods produced in industrialized countries (Rahnema, 2004), the new discourse promotes entrepreneurship to get out of poverty. Behind the discourse on Islamic social finance, is a new capitalist spirit as a framework for action, interpretation, and justification, and as a new model of development and financial inclusion (Boltanski \& Chiapello, 2011). In this context, there is some difficulty in grasping the idea that Islamic social finance is indicative of a changing economy, where the balance between economic efficiency and social impact contributes to the transformation of the market as a space for exchange, where people with demand meet suppliers and enter into transactions, to a community-based institution (Cattelan, 2018, p. i). Beyond the notion of the social impact that remains focused primarily on economic considerations, understanding human relations in exclusively material terms ignores the importance of social relations (Sahlins, 1976, p. 236).

The discourse on maqāsșid al-Sharī 'ah as a critical foundation for an Islamic financial system (Cattelan, 2018 , p. 35) remains general by focusing on five basic needs (al-darūriyyāt al-khamsah) and does not distinguish between general purposes (al-maqāșid al- 'ämmah), the specific purposes (al-maqāsșid al$k h \overline{a s s s a h}$ ), and the auxiliary purposes (al-maqāșid aljuz'iyyah), knowing that this is a very specialized scientific field in which only those may partake who are gifted with finesse of mind and rigor of understanding (Dihlawī, 1992, 1, p. 21). On the other hand, it is necessary to develop behaviors-related purposes (maqāșid al-sulükiyyāt) beyond those related to existing things (maqāșid al-mawjūiāt) to evaluate the management of coherence between what is proclaimed and what is really practiced and its impacts on life in society.

Other than the purely legal and financial aspects, the reflection on maqāsid cannot ignore the progress of research in the sociology of knowledge, history of science and technology, ethics of means, especially of digital means, to evaluate the effect of current technological developments (growth of information technologies, artificial intelligence, etc.) on humans and the way in which societies will be organized in a hyper connected world, but also subject to increasing social and ecological risks. With this evolution, ancient themes find an unexpected vigor, notably the relation between civilization and technics (Mumford, 1934), between man and machine (Mumford, 1967), the technician system which shows that the power and the capacity of reproduction of value is related to technics (Ellul, 1977), the technological bluff that supports the idea that technology is not a system intended to produce neither consumer goods, nor welfare, nor an improvement in people's lives, but first and foremost to produce profit (Ellul, 1988). All these themes are currently beyond the reach of the literature on the maqāssid of Islamic finance driven by insignificance, i.e., following the trend or going with the flow (Castoriadis, 1998, p. 22), under the effect of mimetic desire (Girard, 1961). In this respect, human affairs, irrespective of their nature and of the reference of values, appear to be forged and dominated essentially by relations of desire.

As for the semantic editing, it is necessary to unify the translations knowing that the work of translation is carried out not word by word but 'world to world', to paraphrase a formula of Umberto Eco (2007). A translator must not only know the language, but also grasp the nuances and subtleties that may change the interpretation of what is written, especially when it comes to concepts from the Qur'ān 
and the Sunnah, as the following examples from the book illustrate:

- The word ribā is translated as 'usury, interest' (p. 49), 'usury' (p. 137), 'interest' (p. 149). To consider ribā as usury is to say that the Shari' ah only forbids excessive interest (ribā făhish). It should be noted that rib $\bar{a}$ means "any surplus that does not correspond to an equivalent counter-value" (Ibn al-'Arabī, 2013, 1, p. 189) in terms of goods and services.

To consider here the view of the master of the basics of financial legal maxims (Nadvi, 2015) appears particularly well-suited. For example, any transaction tainted with rib $\bar{a}$ is illegal whether carried out at a minimal or substantial rate.

Other translations are also worth reviewing as the following examples show:

- The word zakāh is translated as 'almsgiving' ( $\mathrm{p}$. xiii), 'annual tax' (p. 38), 'compulsory charity' (p. 46).

- The word gharar is translated as 'extreme risktaking' (p. 103), 'excessive risk' (p. 149), which means that Islam prohibits excessive risk. The most convenient translation is 'alea'.

- The word 'maysir' is translated as 'speculation' (p. 149). The most convenient translation is 'gambling'.
- The word 'waqf' is translated as 'endowment' (p. xiii), 'charitable endowment' (p. 31), 'Islamic endowment' (p. 162), 'charitable trust' (p. 184).

- The word 'falāh' does not mean 'welfare' (p. 6; p. 38), but 'felicity', 'success'. The Arabic translation generally used for the word 'welfare' is 'rafāh'.

- The word 'mașlahah' does not mean 'wellbeing criterion' (p. 18), or 'social benefits of positive externalities' (p. 137), or 'public good' (p. 150) but 'advantage', 'utility'.

- The word 'maslahah mursalah' refers not to the 'public interest' (p. 198) but to a utility that is neither recognized nor canceled by a text in the Qur'ān or Sunnah. However, the jurisconsults have stipulated rules so that the mașlahah is not fictional or invented.

This is in line with an idea stemming from the discussions of a recent book (Belouafi \& al-Bashir, 2019) on the need to unify the translation of Islamic finance concepts. The effort of all is necessary so that such a project can be realized and benefit the whole community of researchers in the field.

Knowing that perfection is not of this world, these remarks do not diminish the importance of this book that enriches the library of Islamic finance. Special thanks to everyone who helped and contributed to making this project and completing it. 


\section{References}

al-Albani, Muḥammad Nasiruddin. (1995). Silsilat alAhädīth al-Sahīhah [Compilation of Authentic Ahādīth]. Riyadh: Maktabat al-Ma'arif.

Belabes, Abderrazak. (2001). Compétitivité nationale, archéologie d'une notion et d'un débat [National Competitiveness, Archeology of a Notion and a Debate], Ph.D. Thesis in Economic Analysis and Policy, Ecole des Hautes Etudes en Sciences Sociales, Paris.

Belabes, Abderrazak. (2017). Is the Waqf a Part of the Third Sector? Awqaf, 33, 12-35.

Belabes, Abderrazak. (2019). Zakat as a Pluridimensional Concept. International Journal of Zakat, 4(1), 67-75.

Belouafi, Ahmed Mahdi., \& al-Bashir, Fadul Abdul Kareem. (Eds.). (2019). Tatwīr al-Munatajāt alMālìyah al-Islāmīyah [Development of Islamic Financial Products]. Jeddah: Scientific Publishing Center, King Abdulaziz University.

Boltanski, Luc., \& Chiapello, Eve. (2011). Le nouvel esprit du capitalisme [The New Spirit of Capitalism]. Paris: Gallimard.

Burlaud, Alain., \& Colasse, Bernard. (2010). Normalisation comptable internationale: le retour du politique? [International Accounting Standardization: The Return of Politics] . Comptabilité - Contrôle - Audit, 16(3), 153-175.

Castoriadis, Cornelius. (1998). Stopper la montée de l'insignifiance [Stop the Rise of Insignificance] . Le Monde diplomatique, August, 22-23.

Cattelan, Valentino. (Ed.). (2018). Islamic Social Finance: Entrepreneurship, Cooperation and the Sharing Economy. London: Routledge.

Champaud, Claude. (2011). Manifeste pour la doctrine de l'entreprise: Sortir de la crise du financialisme [Manifesto for the Doctrine of Enterprise: to get out of the Crisis of Financialism]. Paris: Larcier.

al-Dihlaw̄i, Shāh Walī-Allāh. (1992). Hujjat Allāh alBālighah [The Conclusive Argument from God]. Beirut: Dar Ihya al-Ulum.

Eco, Umberto. (2007). Dire presque la même chose Expériences de traduction [Saying Almost the Same Thing - Translation Experiments]. Paris: Éditions Grasset \& Fasquelle.

Eco, Umberto. (2013). Interview in French with Bulles de Savoir [Video File]. Retrieved from: https://www.youtube.com/watch?v=C8Y0its-bzI

Ellul, Jacques. (1977). Le système technicien [The Technician System] . Paris: Calmann-Lévy.
Ellul, Jacques. (1988). Le bluff technologique [The technological Bluff]. Paris: Hachette.

Fonteneau, Bénédicte., Neamtan, Nancy., Wanyama, Fredrick., Morais, Leandro Pereira., de Poorter, Mathieu., Borzaga, Carlo., ... Ojong, Nathaneal., (2011). Economie sociale et solidaire: notre chemin commun vers le travail décent [Social and Solidarity Economy: our Common Path to Decent Work] . Turin: Centre international de formation de l'Organisation internationale du Travail.

Furchtgott-Roth, Harold. (2016). The Myth of 'Sharing' in A Sharing Economy. Forbes, June 9.

Gaston-Granger, Gilles. (2000). Sciences et réalité [Sciences and Reality]. Paris: Éditions Odile Jacob.

Girard, René. (1961). Mensonge romantique et vérité romanesque [Romantic Lie and Romanesque Truth] . Paris: Grasset.

Godelier, Maurice. (2010). Au fondement des sociétés humaines. Ce que nous apprend l'anthropologie [At the Foundation of Human Societies. What Anthropology Teaches Us]. Paris: Flammarion.

Hacking, Ian. (2008). Entre science et réalité. La construction sociale de quoi? [Between Science and Reality: The Social Construction of What?] . Paris: Éditions La Découverte.

Hamza, Hichem. (Ed.). (2019). Al-Tamwīl wa alIstithmār fi al-Awqā f, [Financing and Investment in Awqāff. Jeddah: Scientific Publishing Center, King Abdulaziz University.

Ibn al-'Arabī, Muḥammad. (2013). Ahkkām al-Qurān, [An Exegesis of the Holy Qur'ān], Beirut: Dar Al Kutub Al Ilmiyyah.

Ibn Qayyim al-Jawziyyah, Muḥammad. (2009). 'Uddat as-Sabirīn wa Dhakhīrat al-Shākirinn [Tools for the Patient and Provisions for the Thankful]. Makkah: Dar Alam al-Fawaid.

Ibn Hanbal, Ahmad. (2001). Musnad al-Imam Ahmad bin Hanbal [Hadith Collection]. Beirut: Mu'assasah Al-Risalah.

Ibn Khaldūn, 'Abd al-Raḥmān. (2004). Al-Muqaddimah [An Introduction to History]. Damascus: Dar Ya'rib.

Ibn Manẓūr, Jamāl al-dīn. (2003). Lisān al- 'Arab [Classic Arabic Dictionary], Beirut: Dar Sader.

Islahi, Abdul Azim. (2014). History of Islamic Economic Thought: Contributions of Muslim Scholars to Economic Thought and Analysis. Cheltenham: Edward Elgar. 
Islahi, Abdul Azim. (2015). Economic Thinking of Arab Muslim Writers during the Nineteenth Century. Basingstoke: Palgrave Macmillan.

Lawson, Tony. (2019). The Nature of Social Reality: Issues in Social Ontology. London: Routledge.

Le Goff, Jean-Pierre. (1996). Le mythe de l'entreprise: Critique de l'idéologie managériale [Myth of the Enterprise: A Critique of Managerial Ideology]. Paris: La Découverte

Marchesnay, Michel. (2009). La rhétorique entrepreneuriale en France: entre sémantique, histoire et idéologie [Entrepreneurial Rhetoric in France: Between Semantics, History and Ideology] . Les éditions de l'ADREG.

Mumford, Lewis. (1934). Technics and Civilization. New York: Harcourt, Brace \& Company.

Mumford, Lewis. (1967). The Myth of the Machine (Vol. I): Technics and Human Development. New York: Harcourt, Brace Jovanovich.

al-Munāwī, 'Abdul Raūf. (2005). Al-Ithāfāt al-Sunniyah bi-al-Ahādìth al-Qudsiyah [The Sunni Dedications with the Sacred Ahädīth]. Damascus: Dar Ibn Kathir.

Nadvi, Ali Ahmad. (2015). Al-Madkhal ila Qawā ìd alFiqh al-Mālì [Introduction to Financial Legal Maxims]. Jeddah: Scientific Publishing Center, King Abdulaziz University
Rahnema, Majid. (2004). Quand la misère chasse la pauvreté [When Misery Hunts Poverty] . Arles: Actes Sud.

Robinson, Joan. (1962). Economic Philosophy. New York: Doubleday \& Company.

Robinson, Rashad. (2014). Virtual Redlining and the Myth of Opportunity in the Sharing Economy. Position Paper for The Open Society Foundation.

Sahlins, Marshall. (1976). Age de pierre, âge d'abondance. L'économie des sociétés primitives [Stone Age Economics]. Paris: Gallimard.

Schoon, Nathalie. (2015). Islamic finance as social finance. In A. Nicholls, R. Paton, \& J. Emerson (Eds.), Social Finance (pp. 572-588). Oxford: Oxford University Press.

Stemler, Abbey. (2017). The Myth of the Sharing Economy and its Implications for Regulating Innovation. Emory Law Journal, 67(2), 197-241.

al-Tabarani, Sulaiman bin Ahmad. (1994). Al-Mu'jam al-Kabeer [Hadith Collection] . Cairo: Maktabah Ibn Taymiyyah.

Zwirn, Hervé. (2000). Limites de la connaissance [Limits of Knowledge]. Paris: Éditions Odile Jacob.

Abderrazak Belabes, is a researcher at the Islamic Economics Institute, King Abdulaziz University. He holds an electronic Engineering degree, a Master of Science in econometrics, and a $\mathrm{PhD}$ in economic analysis and policy from the School of High Studies in Social Sciences (EHESS), Paris. He is a member of the Strasbourg University Research Team in Islamic finance and a member of the editorial board of the 'Cahiers de la finance Islamique', the first specialized scientific journal in the field established in France. His main research interests beyond the subject matter - focus on economic methodology, in the broadest sense of the term, which includes the distinction between the existence of the object (ontology), its representation (imago), and the way to know it (epistemology).

E-mail: abelabes@kau.edu.sa 


\title{
مراجعة كتاب
}

\section{التمويل الإسلامي الاجتماعي: ريادة الأعمال، التعاون والاقتصياد التشـاركي تحرير: فالنتينو كتلان}

\author{
الناشر: روتليدج، لندن، 2018م، 222 صفحة \\ مراجعة: عبد الرزاق سعيد بلعباس \\ باحث، معهد الاقتصاد الإسلامي، جامعة الملك عبد العنيز، جدة، المملكة العببية السعودية
}

مستخلص: تهدف المراجعة العلمية إلى مناقشة مفهوم التمويل الاجتماعي الإسلامي، أو ماهية التمويل

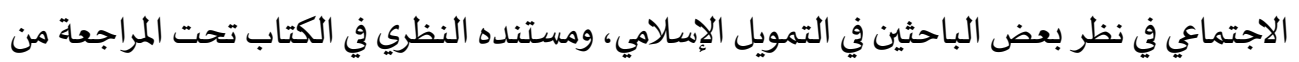

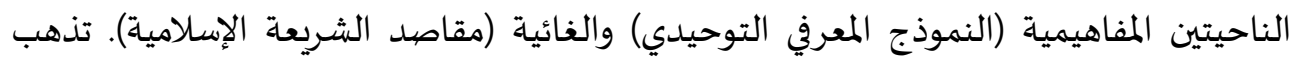

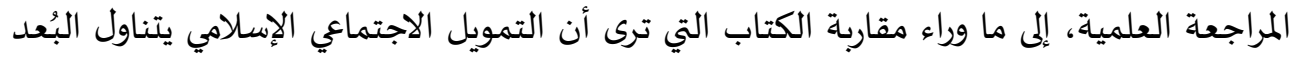

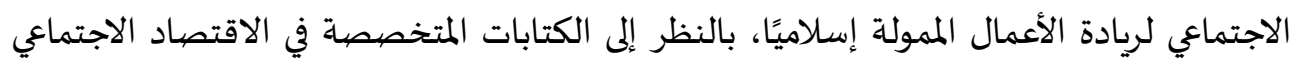

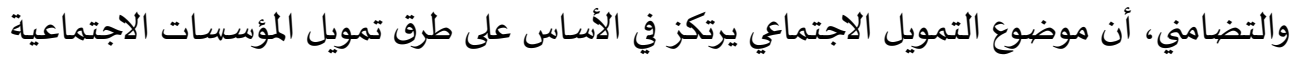

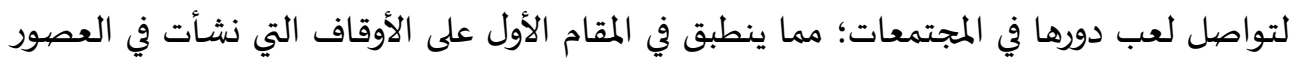
القديمة منذ تأسيس الكعبة الشريفة. هذا يعني أن الوقف هو أكثر من مجرّد أداة من أدوات التمويل

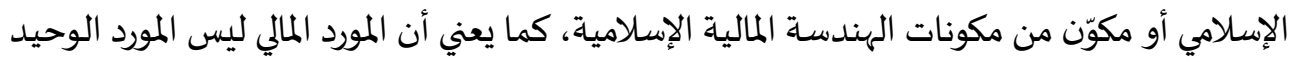

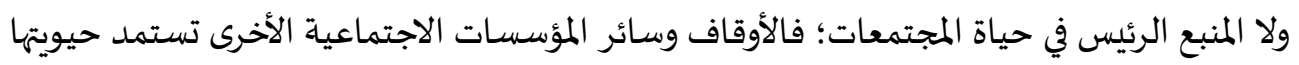
بداية من الروابط الاجتماعياة، وهي كنز لا يقدر بثمن يوفر الحماية على مدى الميات الحياة. فهل نُؤثر ما هو

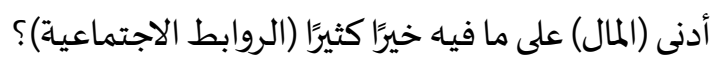
الكلمات الدالة: التمويل الإسلامي الاجتماعي، النموذج المعرفي التوحيدي، مقاصد الشربعة، ريادة الأعمال، تغول القطاع المالي.

تصنيف B41, G23, Z12 :JEL تصنيف B4, I4:KAUJIE 